\title{
Unique morphologies of Encheliophis vermiops (Carapidae) with revised diagnosis of the genus
}

\author{
Eric Parmentier - Deborah Lanterbecq • \\ Maité Todesco • Igor Eeckhaut
}

Received: 20 March 2009/Revised: 8 August 2009/Accepted: 26 September 2009

(C) The Ichthyological Society of Japan 2009

\begin{abstract}
Encheliophis vermiops was first briefly described in 1990 on the basis of three specimens. This study validates this species and provides previously unrecorded useful characters to realise the identification: (1) the forward orientation of the palatine teeth, (2) the enlarged teeth of the third basibranchial, (3) the particularly well-developed pharyngeal apparatus, (4) the unpigmented band along the base of anal fin and (5) the insertion of the primary sonic muscle on the parasphenoid. Moreover, the particular morphology of Encheliophis vermiops forces us to reconsider the diagnosis of the genus.
\end{abstract}

Keywords Carapidae Parasite $\cdot$ Diagnosis ·

Pharyngeal jaws

\section{Introduction}

The family Carapidae (Ophidiiformes), known as pearlfish, contains an ecologically diverse group of marine fishes. Several species that belong to the genera Onuxodon, Carapus and Encheliophis are well known for their unusual behaviour of entering and living inside invertebrate hosts such as species of the Holothuroidea, Asteroidea and Bivalvia (Arnold 1956; Trott 1981; Markle and Olney

E. Parmentier $(\square)$

Laboratoire de Morphologie Fonctionnelle et Evolutive, Institut de Chimie, Université de Liège, Bât. B6C,

4000 Liège, Belgium

e-mail: E.Parmentier@ulg.ac.be

D. Lanterbecq · M. Todesco $\cdot$ I. Eeckhaut

Marine Biology, University of Mons-Hainaut,

6 Av. Champ de Mars, 7000 Mons, Belgium
1990). The species that belong to the genus Encheliophis are parasites of holothurians (Parmentier et al. 2000; Parmentier and Das 2004). Encheliophis is diagnosed by 11 autapomorphies (Parmentier et al. 2000), among which are two characters easily observable in the field: the maxillaries and premaxillaries are united by short connective fibres to function as a unit, and both elements are bound to the skin, preventing a large gape (Parmentier et al. 1998). Five Encheliophis are recognised: Encheliophis gracilis (Bleeker 1856), Encheliophis sagamianus (Tanaka 1908), Encheliophis vermiops Markle and Olney 1990, Encheliophis vermicularis Müller 1842, and Encheliophis chardewalli Parmentier 2004. Encheliophis vermicularis and E. chardewalli are distinctive among previously known carapids lacking pectoral fins (Müller 1842; Markle and Olney 1990; Parmentier 2004). Encheliophis gracilis is quite common and is easily found from East Africa to French Polynesia, whereas E. sagamianus has only been found in Japan. Encheliophis vermiops was briefly described in 1990 on the basis of two adults found in the collection of the Australian Museum and a juvenile observed in the J.L.B. Smith Institute of Ichthyology (RUSI) in South Africa. The description is mainly based on their colour in ethanol, and on morphometric and meristic data (Markle and Olney 1990). An additional nine specimens of E. vermiops were recently caught on the Great Reef of Toliara (Madagascar). The aim of this paper is to validate Encheliophis vermiops as a species and to understand their way of life based on a detailed morphological description.

\section{Materials and methods}

Sea cucumbers Holothuria fuscopunctata were collected between 0 and $10 \mathrm{~m}$ depth on the Great Reef of Toliara 
$\left(23^{\circ} 25^{\prime} 23^{\prime \prime} \mathrm{S}\right.$ and $\left.49^{\circ} 39^{\prime} 43^{\prime \prime} \mathrm{E}\right)$ by fishermen of Ankilibe village during January 2007. A total of 9 Encheliophis vermiops (75-99 $\mathrm{mm}$ in total length: TL, 5.3-6.7 $\mathrm{mm}$ in head length: HL) were found inside the sea cucumbers. Four adult E. vermiops specimens from Toliara were alizarin stained (Taylor and Van Dyke 1985). Three other adult specimens were dissected and examined with a Wild M10 (Leica) binocular microscope equipped with a camera lucida. Measurements were made to the nearest $0.1 \mathrm{~mm}$. Three specimens (of which one was cleared and stained) were placed in the collection of the Australian Museum and were recorded as AMS I.44101-001. Two other specimens were placed in the collection of the Smithsonian Museum of Natural History and were recorded as USNM 394996. The other specimens were placed in the private collection of the Laboratory of Functional and Evolutionary Morphology (University of Liège).

The present specimens were compared to radiographs of the holotype (AMS IB. 5245) and paratype (AMS IB. 5244) of E. vermiops, and to cleared and stained specimens of E. vermicularis (VIMS 09600, 123-148 mm TL). Other comparative specimens came from the private collection of the University of Liège. Encheliophis gracilis: 170$230 \mathrm{~mm}$ TL, 5 specimens, E. sagamianus : $115 \mathrm{~mm}$ TL, 1 specimen, Encheliophis vermicularis: 123-148 mm TL, 2 specimens, Carapus mourlani (Petit 1934): 60-110 mm TL, 3 specimens, Carapus boraborensis (Kaup 1856): 130-180 mm TL, 3 specimens, Carapus homei (Richardson 1844): 80-125 mm TL, 2 specimens, Carapus dubius (Putnam 1874): 92-120 mm TL, 2 specimens and Carapus acus (Brunnich 1768): 74-125 mm TL, 4 specimens.

The cephalic morphology of the genus Encheliophis has been thoroughly described by Markle and Olney (1990) and by Parmentier et al. (1998, 2000). The sound-producing apparatus is described in detail in Parmentier et al. (2003). Counts and measurements followed the methods of Williams and Shipp (1982) and Markle and Olney (1990).

\section{Results}

The following description focusses on the characters that distinguish the species. Meristic data are given in Table 1. TL was between 75 and $99 \mathrm{~mm}$; HL was between 5.3 and $6.6 \mathrm{~mm}$. The body lacks pelvic and caudal fins (Fig. 1). The anal fin originates behind the opercle. It is longer than the dorsal fin, with both fins meeting at the posterior tip of the body. The body pigmentation consists of large stellate melanophores. Dorsal, anal and pectoral fins are unpigmented. Moreover, a larger unpigmented band is found along the base of the anal fin (Fig. 1).

Skull morphology. The maxilla is toothless. Six outer cardiform teeth are present at the anterior end of the premaxilla; their orientation is perpendicular to the axis of symmetry (Fig. 2). Small conical teeth are organised in one row along this bone. The conical teeth on the anteriorly on the premaxilla appear to be larger. The dentary displays a single row of external conical teeth that curve toward the inside of the mouth. Small conical teeth are arranged in a single row; these teeth curve forward (Fig. 2). The vomer has one to two large prominent teeth.

The pharyngeal jaws are as long as $2 / 3$ of the neurocranium length and present well-developed teeth. The teeth are present in a single row on the elongated third basibranchial (Fig. 3). This row is prolonged by two rows situated at the level of the fifth ceratobranchials, which form the lower pharyngeal jaws (LPJ). The upper pharyngeal jaws (UPJ) present two rows of teeth medially parallel to the ventral teeth. The three bones of the UPJ (pharyngobranchials 2, 3 and 4) are very elongated and overlap each other. The four branchial arches bear serrated branchiostegal buttons, while the first ceratobranchial additionally displays three welldeveloped branchiospines. The lateral ethmoid is U-shaped and is composed of two shelves: the first, lateral ethmoid (part a), projects laterally and the second, lateral ethmoid (part b), is in contact with the frontal.

Table 1 Meristic characters of Encheliophis vermiops caught in Tulear and from the study $(M \& O)$ of Markle and Olney (1990)

\begin{tabular}{|c|c|c|c|c|c|}
\hline & Specimen 1 & Specimen 2 & Specimen 3 & Specimen 4 & $M \& O$ \\
\hline Dorsal fin rays to 31 st vertebra & 29 & 34 & 34 & 32 & 28 \\
\hline Anal fin rays to 31 st vertebra & 36 & 38 & 40 & 38 & 40 \\
\hline Pectoral fin rays & 15 & 15 & 15 & - & $15-16$ \\
\hline Branchiostegal ray & 7 & 7 & 7 & 7 & - \\
\hline Precaudal vertebrae & 23 & 23 & 18 & 20 & $20-22$ \\
\hline Total vertebrae & 109 & 98 & 109 & 104 & - \\
\hline Vertebrae to dorsal fin origin & 13 & 13 & 11 & 11 & 16 \\
\hline Vertebrae to anal fin origin & 6 & - & 5 & 8 & 5 \\
\hline Vertebrae facing swimbladder plate & $3-5$ & $3-5$ & $3-5$ & $3-5$ & - \\
\hline Vertebrae facing a scale & 82 & 68 & 75 & 77 & - \\
\hline
\end{tabular}

- Not available 
a
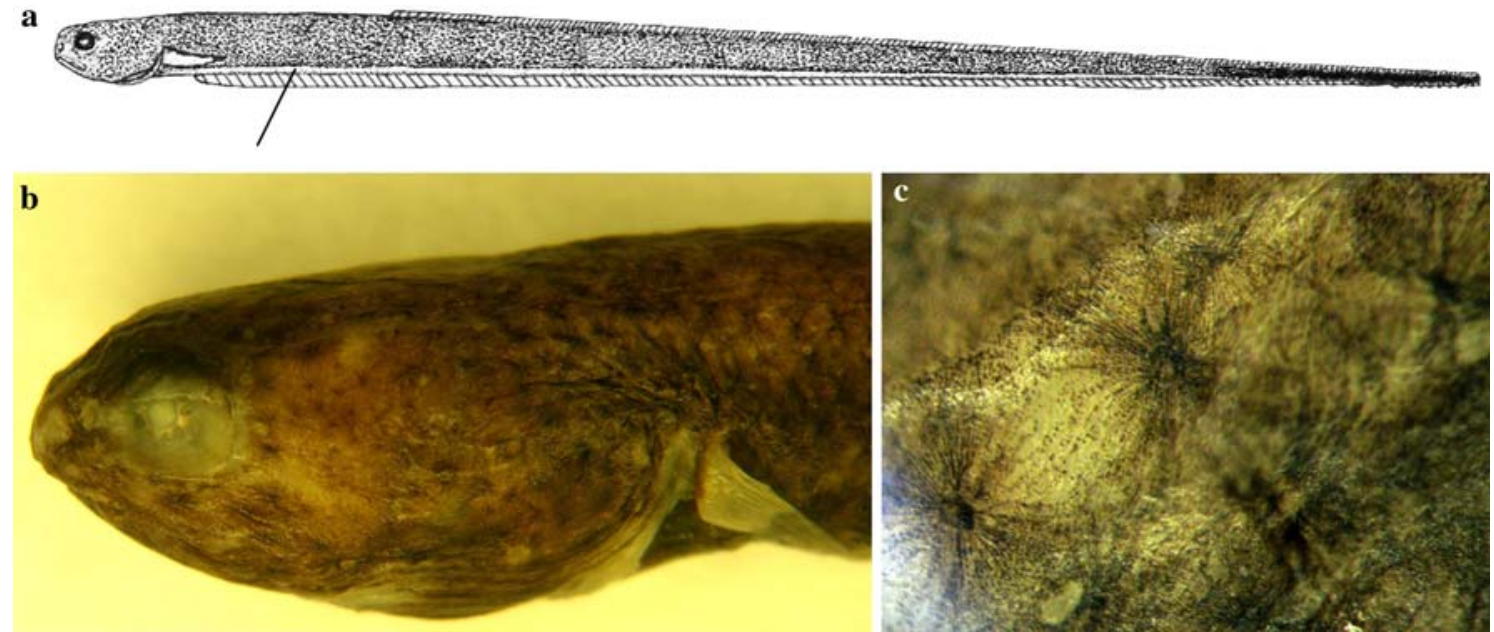

Fig. 1 Left lateral view of Encheliophis vermiops. a Holotype (AMS IB. 5245: modified from Markle and Olney 1990). b Head of a preserved specimen in alcohol—note the unpigmented pectoral fin. c Stellate melanophore on cheek. Small black line indicates the unpigmented band along the anal fin base
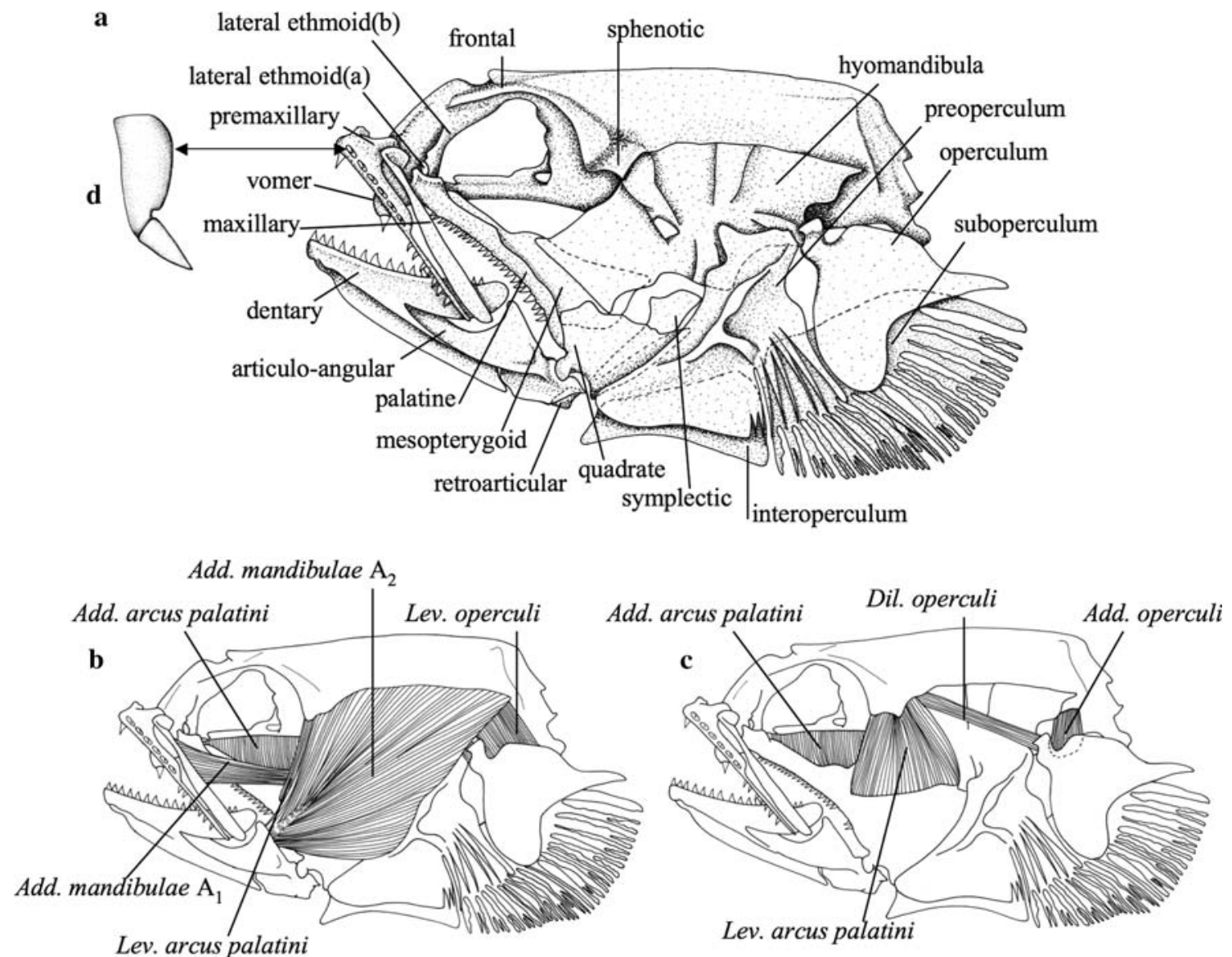

Fig. 2 Left lateral view of the skull (a) and of the muscles $(\mathbf{b}, \mathbf{c})$ in Encheliophis vermiops. Adductor mandibulae $\mathrm{A}_{2}$ and $\mathrm{A}_{1}$, and levator operculi are removed in (c). d Cardiform tooth in lateral view (they are perpendicular in a). Add adductor, Lev levator, Dil dilatator 

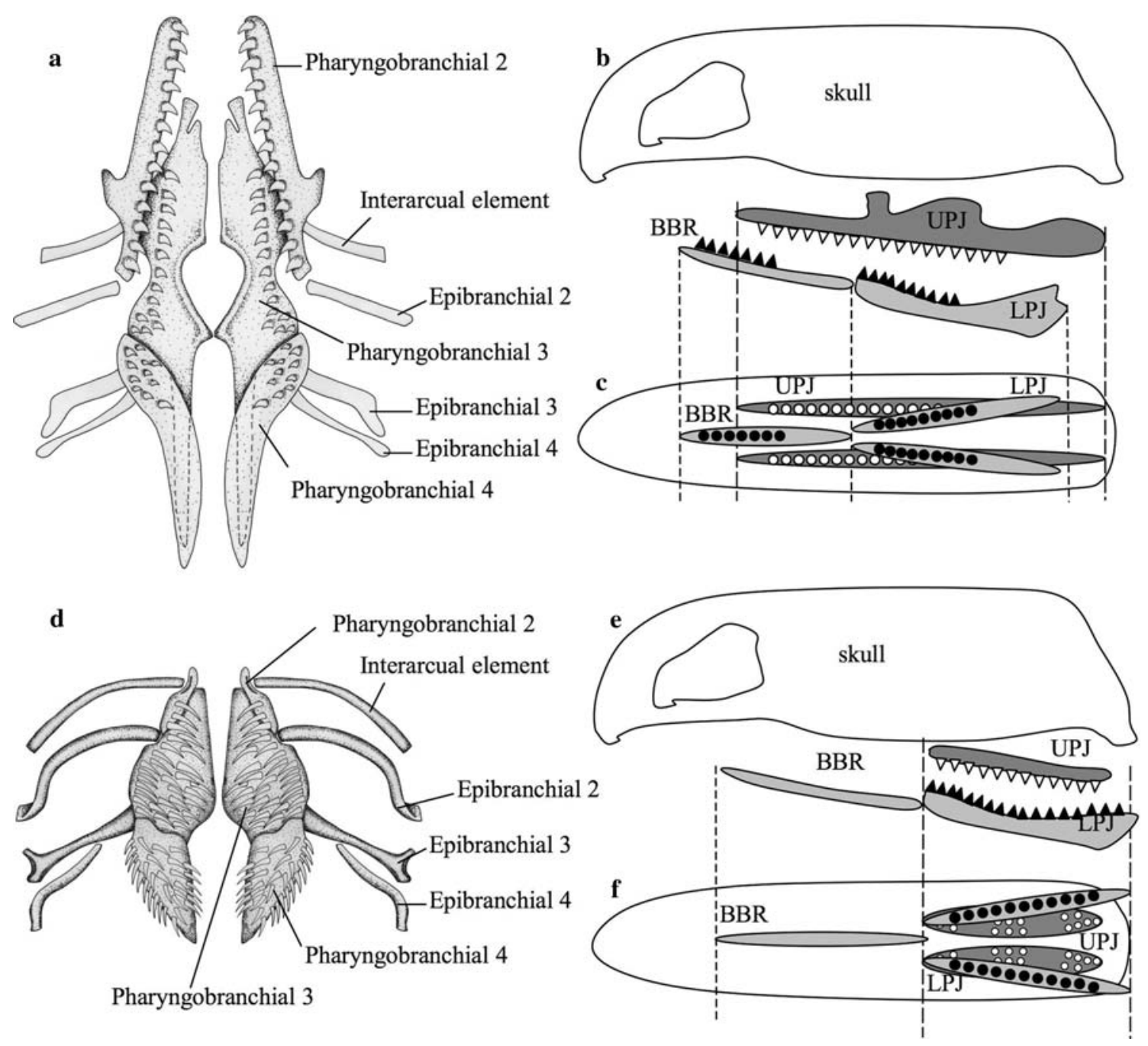

Fig. 3 Ventral view of the upper pharyngeal jaws in Encheliophis vermiops (a) and in Encheliophis gracilis (d). Schematic positioning of the upper pharyngeal jaws $(U P J)$ and lower pharyngeal jaws

$(L P J)+$ basibranchials 1-3 $(B B R)$ in relation to the skull in lateral view in E. vermiops (b) and in E. gracilis (e), and in ventral view in E. vermiops (c) and in E. gracilis (f)

The quadrate is anterior to a vertical line passing through the anterior articulation of the hyomandibular on the neurocranium. The operculum forms a rounded plate. The posterior part of preoperculum and interoperculum are cut in small strips. The hyoid arch bears seven branchiostegal rays. The metapterygoid is reduced and overlaps only the hyomandibular.

Sound-producing mechanism. Specimens possess between 98 and 109 vertebrae, including 18-23 precaudal vertebrae (Table 1). At the level of the lateral line, they have on each side a small scale per vertebra until the 82nd68th vertebra. The first two vertebrae each bear a rodlike articulated epineural. The third vertebra forms an articulated elongated and enlarged plate, which covers the anterior part of the swimbladder and reaches the fifth vertebra. The fourth epineural rib is greatly reduced and overlies the swimbladder plate (Fig. 4). From the fourth vertebra, all the other precaudal vertebrae bear on each side a short parapophysis (Fig. 4). Dorsal to the fourth neural spine is one supraneural cartilage. The neural spines of these vertebrae are very short and are nearly horizontal. The swimbladder size, extending from the third to the eighth vertebra, corresponds to only $30 \%$ of the abdominal cavity. The presence of primary sonic muscles indicates that they should be able to make sounds (Fig. 4). However, E. vermiops is unique in having its anterior insertion just behind the orbit, on the parasphenoid, and not on the orbital roof, as is the case in other Carapini. The secondary sonic muscles are also present. They are inserted on the epiotic and on the proximal part of the first two articulated epineurals. Encheliophis vermiops possesses a muscle extending from the distal part of the first epineural to the posterior part of the pectoral girdle. This muscle could also play a role in the sound that E. vermiops should be able to produce. 


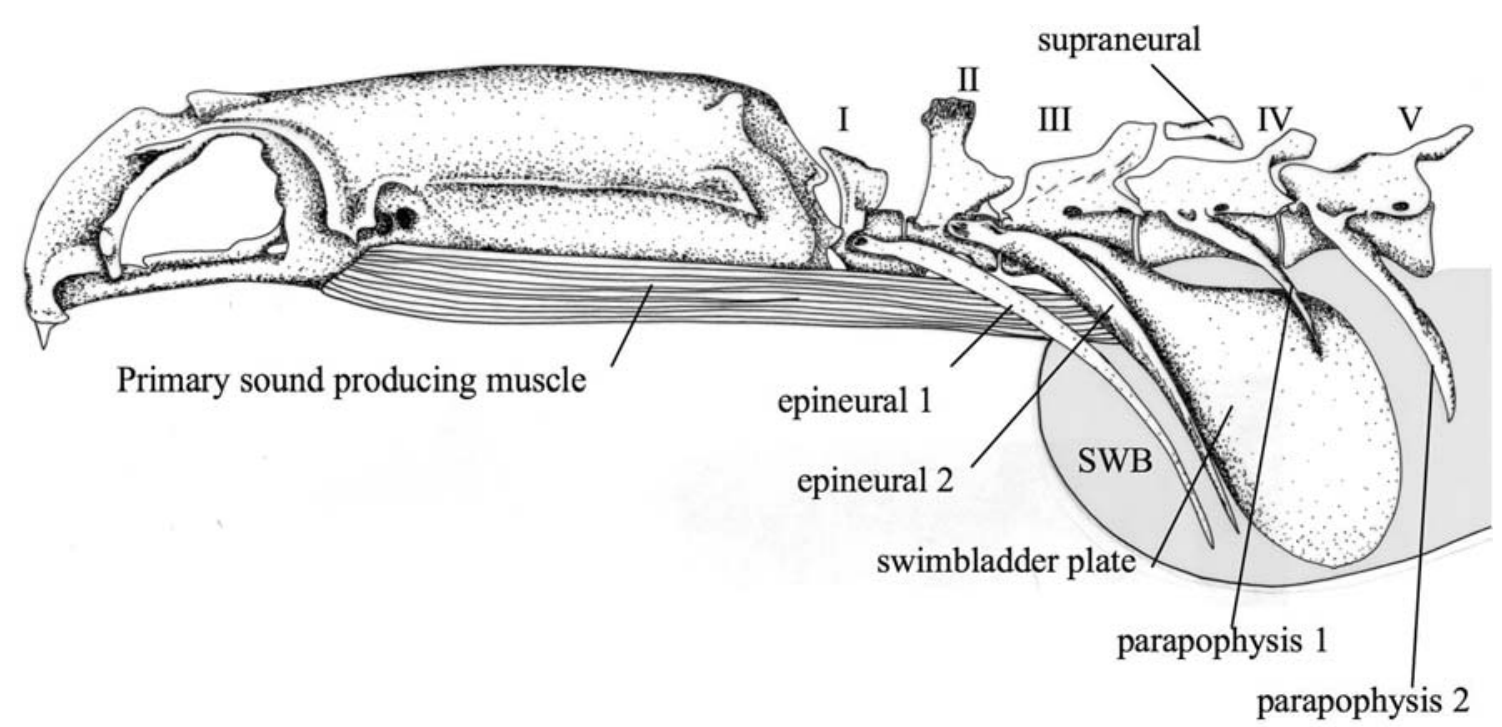

Fig. 4 Left lateral view of the skull and the sound-producing apparatus in Encheliophis vermiops. Secondary sound producing muscles are not shown

Head musculature. The main difference between the head muscles of E. vermiops and of other Carapini is found in the simple division of the adductor mandibulae bundles. There are usually six adductor mandibulae bundles in Carapini. Encheliophis vermiops possess only three adductor mandibulae bundles: adductor mandibulae $\mathrm{A}_{1}$, adductor mandibulae $\mathrm{A}_{2}$ and adductor mandibulae $\mathrm{A} \omega$ (Fig. 2). $A_{1}$ originates on the anterior part of the hyomandibular and on the inner anterior part of the maxillary. $\mathrm{A}_{2}$ is the most external and the thickest, originating from the pterotic, hyomandibula and preoperculum, and inserting on the inner side of the articulo-angular. The adductor mandibulae $\mathrm{A} \omega$ also extends from the inner part of the dentary to the quadrate. The dilatator operculi is also formed of one bundle in E. vermiops (Fig. 2), whereas there are two in other Carapini. Other muscles associated with the buccal apparatus (adductor arcus palatini, levator arcus palatini, sternoyhoideus, geniohyoideus) are the same as those found in other Carapini.

The dissections of the digestive tracts showed the presence of unidentified soft tissue in the intestine. No hard pieces such as calcareous plate, spicules, bones, cuticle or sagittae were found.

\section{Discussion}

In their diagnosis, Markle and Olney (1990) note that Encheliophis vermiops is a holothurian-inhabiting, diminutive species of Encheliophis with an adnate maxilla, 20 22 precaudal vertebrae, 15-16 pectoral fin rays, 19-20 anal fin rays anterior to dorsal fin origin and 16 vertebrae to dorsal fin origin. They also add: the posterior position of the maxilla is partly adnate; cardiform teeth are present on the premaxilla; enlarged fangs are absent; dentary and palatine bear tightly spaced triangular teeth, which appear to interdigitate; the swimbladder is short without a pseudochamber. Most of these characters are not useful because the Carapini species have overlapping meristic values, cardiform teeth and small teeth on the dentary (Markle and Olney 1990; Parmentier et al. 2000). In this diagnosis, the presence of the adnate maxilla allows us only to ascertain that the specimens in this study belong to the Encheliophis (Parmentier et al. 2000). As a result, the diagnosis of E. vermiops in Markle and Olney (1990) is not useful for recognising the species. It is also impossible to use these characters in the field.

Three characters are useful to distinguish, in a noninvasive way, E. vermiops from all other Encheliophis species: (1) the forward orientation of the palatine teeth, (2) the enlarged teeth of the third basibranchial and (3) the particularly well-developed pharyngeal apparatus. These characters are not found in the diagnosis of Markle and Olney (1990). However, the third character is clearly visible on the X-rays of the holotype (AMS IB. 5245) they deposited in the Australian Museum. Pharyngeal apparatus of Encheliophis is usually no longer than half the length of the cranium (Parmentier et al. 2000). The pharyngeal apparatus of Encheliophis gracilis is illustrated as an example for comparison with E. vermiops (Fig. 3).

The anterior insertion of the primary sonic muscle is a fourth distinctive character. In all other Encheliophis (and Carapidae) in which this character has been examinated, the anterior insertion of this muscle is usually on the orbital 
roof, on the inner face of the frontal (Parmentier et al. 2002).

In Carapini, the distinction between commensal species (Carapus) and the parasitic species (Encheliophis) has been corroborated by comparisons of their morphological features (Parmentier et al. 1998, 2000; Parmentier and Das 2004). The Carapus species have retained an apparatus enabling them to grasp and retain hard and elusive prey: strong jaws, high coronoid processes, a considerable dentition, a slight protraction of the upper jaws, the capacity to open the mouth wide and the presence of well-developed adductor mandibulae (Markle and Olney 1990; Parmentier et al. 1999, 2000). Encheliophis species feed on the soft internal tissues of their hosts. The endoparasitic lifestyle does not impose the same constraints as food intake in open water. This situation is reflected in their morphology: the upper and lower jaws are less robust and thinner, with shorter coronoid processes on the dentary and articuloangular; the dentition is weakly developed at the level of the buccal and pharyngeal apparatus. Finally, the upper jaws lack mobility due to the insertion of the adductor mandibulae $A_{1}$ directly on the maxillary (instead of on the maxillo-mandibular ligament) and the presence of short connective fibres between the maxillaries and premaxillaries, preventing independent movements. As in other Encheliophis, E. vermiops has a uniserial set of teeth on the jaws and displays no wide mouth opening because of the lack of mobility between the maxillaries and premaxillaries and the insertion of the adductor mandibulae $\mathrm{A}_{1}$ directly on the premaxillary. The adductor mandibulae $\mathrm{A}_{2}$ appear to be even less developed, and it was not possible to discern different bundles, as is the case in other Carapini species (Parmentier et al. 1998). These characters support the parasitic lifestyle of E. vermiops. Moreover, only soft tissues were found in the digestive tract (personal observation).

Considering the morphology of E. vermiops, the Encheliophis diagnosis proposed by Parmentier et al. (2000) has to be reconsidered. Different Encheliophis autapomorhies, such as (1) three well-developed gill rakers (Williams 1984; Shen and Yeh 1987), (2) a maxillary ending in a bump (Parmentier et al. 2000) or (3) the absence of small conical teeth on the posterior part of the premaxillary (Parmentier et al. 2000), appear to be insufficient to diagnose the genus. Here is a revised diagnosis for Encheliophis: Carapidae species lacking all the following: pelvic fins, a rockerbone, fangs, a diastema on the premaxillary and dentary, and a maxillo-mandibular ligament; but Carapidae possessing: a single row of small, evenly spaced teeth on the dentary, maxillary and premaxillary bound by skin to the head, cardiform teeth on the premaxillary and, in certain cases, small conical teeth on the premaxillary.

Acknowledgments We would like to thank Richard Rasolofonirina and his team for their help in collecting fishes. This study was supported by FRFC grant no. 2.4.583.05 from the Fonds National de la Recherche Scientifique of Belgium. Dr. J.F. Williaws and an anonymous referee kindly proposed constructive comments in an earlier version. E.P. is research associate of the FRS-FNRS.

\section{References}

Arnold DC (1956) A systematic revision of the fishes of the teleost family Carapidae (Percomorphi, Blennioidea), with description of two new species. Bull Br Mus (Nat Hist) 4:247-307

Bleeker P (1856) Vijrae bijdrage tot de kinnis der ichthyologiche fauna van de Banda-eilander. Nat Tijdschr Ned-Ind 11:93-110

Markle DF, Olney JE (1990) Systematics of the pearlfishes (Pisces: Carapidae). Bull Mar Sci 47:269-410

Müller J (1842) Fortsetzung der untersuchungen uber die swimblase der fishes mit bezug auf einige neue fischgattungen. Ber Verh Preuss Akad Wiss 1842:202-210

Parmentier E (2004) Encheliophis chardewalli: a new species of Carapidae (Ophidiiformes) from French Polynesia, with a redescription of Encheliophis vermicularis. Copeia 2004:62-67

Parmentier E, Das K (2004) Commensal vs parasitic relationship between Carapini fish and their host: some further insight through $\delta^{13} \mathrm{C}$ and $\delta^{15} \mathrm{~N}$ measurements. J Exp Mar Biol Ecol 310:47-58

Parmentier E, Chardon M, Poulicek M, Bussers JC, Vandewalle P (1998) Morphology of the buccal apparatus and related structures in four species of Carapidae. Aust J Zool 46:391-404

Parmentier E, Castillo G, Chardon M, Vandewalle P (2000) Phylogenetic analysis of the pearlfish tribe Carapini (Pisces: Carapidae). Acta Zool (Stockholm) 81:293-306

Parmentier E, Chardon M, Vandewalle P (2002) Preliminary study on the ecomorphological signification of the sound-producing complex in Carapidae. In: Aerts P, D'Août K, Herrel A, Van Damme R (eds) Topics in functional and ecological vertebrate morphology. Shaker Publishing, Maastricht, pp 139-151

Parmentier E, Vandewalle P, Lagardère JP (2003) Sound producing mechanisms and recording in Carapini species (Teleostei, Pisces). J Comp Physiol A 189:283-292

Shen SC, Yeh HS (1987) Study on pearlfishes (Ophidiiformes: Carapidae) of Taiwan. J Taiwan Mus 40:45-56

Tanaka S (1908) Description of eight new species of fishes from Japan. Ann Zool Jpn 7:27-46

Taylor WR, Van Dyke GC (1985) Revised procedure for staining and clearing small fishes and other vertebrates for bone and cartilage study. Cybium 2:107-119

Trott LB (1981) A general review of the pearlfishes (Pisces, Carapidae). Bull Mar Sci 31:623-629

Williams JT (1984) Synopsis and phylogenetic analysis of the pearlfish subfamily Carapinae (Pisces: Carapidae). Bull Mar Sci 34:386-397

Williams JT, Shipp RL (1982) A new species of the genus Echiodon (Pisces: Carapidae) from the eastern Gulf of Mexico. Copeia 1982:296-397 